\title{
Problem naruszeń praw mniejszości wyznaniowych na przykładzie Donieckiej Republiki Ludowej i Ługańskiej Republiki Ludowej
}

\section{The Problem of Violations of Religious Minorities' Rights on the Example of Donetsk People's Republic and the Luhansk People's Republic}

\section{Abstract}

The armed conflict in eastern Ukraine and establishing the Donetsk People's Republic (DPR) and the Luhansk People's Republic (LPR) resulted in many complications and tensions, both in international relations, and within the territories of those self-proclaimed republics. Violation of rights of religious minorities is one of such problems. It includes various forms of unlawful deeds, ranging from intimidation to killings. Such a situation creates grounds for legal responsibility of subjects involved in above mentioned violations. However, a crucial difficulty in this respect is enforcement of justice in practice. The difficulty results from two factors. First factor is that territories in question are beyond the effective control of Ukraine; it prevents Ukrainian authorities from taking legal steps against individuals who committed crimes. The second problem is that both self-proclaimed republics do not exist in the light of law, and thus they cannot take responsibility, also under international law. A change of this state of affairs would be possible only after ultimate settlement of legal status of eastern regions of Ukraine, and it requires a good will of all sides being engaged in the conflict. 
Keywords: Donetsk People’s Republic, Luhansk People’s Republic, religious discrimination, religious minorities, Ukraine

\section{Проблема нарушений прав религиозных меньшинств на примере Донецкой Народной Республики и Луганской Народной Республики}

\section{Аннотация}

Следствием военного конфликта на востоке Украины и установления Донецкой Народной Республики (ДНР) и Луганской Народной Республики (ЛНР) стали многочисленные осложнения, а также напряженность - как в международных отношениях, так и в пределах двух сепаратистских республик. Одной из таких проблем являются нарушения прав религиозных меньшинств, которые принимают различные формы неправомерных поступков - от запугивания по убийства. Отсутствие реакции руководящих органов ДНР и ЛНР на такие нарушения, а иногда даже и их вдохновляющая роль в этих действиях, как и создание условий для дискриминационных практик дают основы для юридической ответственности не только непосредственных исполнителей, но и руководящих органов двух квази-государств. Однако, практическая возможность совершения правосудия за эти неправомерные действия составляет крайнюю трудность. Изменить положение дел можно лишь путем окончательного урегулирования юридического статуса восточных районов Украины, но это требует доброй воли всех сторон конфликта.

Ключевые слова: Донецкая Народная Республика, Луганская Народная Республика, религиозная дискриминация, религиозные меньшинства, Украина

\section{Wprowadzenie}

W Oolność religijna jest jednym z kluczowych zagadnień, jeśli chodzi o szeroko rozumiane prawa człowieka. Kwestie związane z religią są przy tym tematem niezwykle wrażliwym, mogącym łatwo prowadzić do nieporozumień, a nawet konfliktów społecznych. Zapewnienie właściwej koegzystencji w państwie osób wyznających różne religie jest zatem jednym z najważniejszych zadań władz. Należy zaznaczyć, że równe prawa do wyznawania i praktykowania religii powinny dotyczyć wszystkich, nie tylko osób wyznających dominującą religię w danym kraju, ale też osób należących do mniejszości wyznaniowych. Co 
więcej, ochrona wolności religijnej jest współcześnie przedmiotem regulacji nie tylko prawa wewnętrznego, ale i międzynarodowego.

Szczególne wyzwania w zakresie ochrony praw mniejszości wyznaniowych pojawiają się w przypadku podmiotów niestabilnych, objętych niepokojami społecznymi czy konfliktami zbrojnymi, zwłaszcza na terenach, gdzie rząd centralny nie sprawuje efektywnej kontroli. $Z$ tego rodzaju sytuacją mamy do czynienia w przypadku Donieckiej Republiki Ludowej (DRL) i Ługańskiej Republiki Ludowej (ŁRL) - podmiotów nieuznawanych na arenie międzynarodowej, powstałych w wyniku trwającego od $2014 \mathrm{r}$. konfliktu zbrojnego na wschodzie Ukrainy. Celem niniejszego opracowania jest określenie, jak w świetle prawa międzynarodowego przedstawia się sytuacja mniejszości wyznaniowych, zaprezentowanie naruszeń tych praw na terenach DRL i ŁRL oraz wskazanie prawnych konsekwencji tych naruszeń.

\section{Charakter konfliktu zbrojnego na wschodzie Ukrainy oraz status prawny Donieckiej Republiki Ludowej i Ługańskiej Republiki Ludowej}

Analizując problem naruszeń praw mniejszości wyznaniowych na terenie DRL i ŁRL, należy w pierwszej kolejności przybliżyć w zarysie ich genezę, prezentując przy tym ocenę ich faktycznego funkcjonowania oraz dokonując kwalifikacji prawnej trwającego od 2014 r. konfliktu zbrojnego na wschodzie Ukrainy. Konflikt ten oraz powstanie DRL i ŁRL mają swoją genezę w protestach na kijowskim Majdanie Niezależności, wskutek których odsunięty od władzy został dotychczasowy prezydent Ukrainy, Wiktor Janukowycz. Formalne proklamowanie niepodległości obydwu republik nastąpiło 12 maja 2014 r., po przeprowadzonych uprzednio referendach, w których (zdaniem zwolenników niepodległości) zdecydowana większość osób w nich uczestniczących opowiedziała się za odłączeniem od Ukrainy. Należy przy tym podkreślić, że referenda nie spotkały się z akceptacją na arenie międzynarodowej, zaś niepodległości tych republik nie uznało dotąd żadne suwerenne państwo. Odłączenia się wspomnianych terenów oczywiście nie uznała również Ukraina, traktując separatyzm jako naruszenie swojej integralności terytorialnej i (dążąc do odzyskania nad nimi efektywnej kontroli) rozpoczęła tzw. „operację antyterrorystyczną” (ATO). 
Wsparcia separatystom udzieliła natomiast Rosja, której pomoc przybierała różne formy, począwszy od dostarczania zaopatrzenia, poprzez szkolenie rebeliantów, aż do bezpośredniego zaangażowania rosyjskich sił zbrojnych na terytorium Ukrainy (Grzywaczewski, 2015, s. 91). Mówiąc o wsparciu Rosji, warto też zauważyć, że utworzenie DRL i ŁRL wpisuje się w koncepcję tzw. „Ruskiego miru”. Koncepcja ta zakłada integrację obszaru byłego ZSRR i opiera się na założeniu odrębności cywilizacyjnej i duchowej wspólnoty rosyjskojęzycznej, z uwzględnieniem szczególnej roli prawosławia i przewodniej roli Rosji w świecie rosyjskojęzycznym i prawosławnym. Wprawdzie projekt „Ruskiego miru” miał początkowo wymiar raczej kulturalny (fundacja Фонд „Русский мир” utworzona została w 2007 roku w celu promocji rosyjskiego języka i kultury za granicą), jednak wkrótce uzyskał on wymiar polityczny. Doktryna ta w wymiarze politycznym dopuszcza bowiem interwencję w obronie „Ruskiego miru” (Delong, 2020, s. 50-64), wskutek czego stała się podbudową polityki Rosji wobec Ukrainy oraz doktryną legitymizującą najpierw aneksję Krymu, a następnie wsparcie dla separatystów na wschodzie tego państwa.Z punktu widzenia tematu niniejszego opracowania niemniej ważny jest też aspekt ideologiczny wspomnianej doktryny, zakładający prymat prawosławia pod przewodnictwem Rosji, w opozycji do zlaicyzowanego świata zachodniego; jak twierdzą wręcz niektórzy wysocy rangą rosyjscy duchowni i urzędnicy, prawdziwi wierni powinni albo dołączyć do „Ruskiego miru" albo zginąć w bezbożnej Europie (Gaufman, 2020, s. 66). W tym ujęciu można wręcz powiedzieć, że zwolennicy tej koncepcji roszczą sobie prawo do przedstawiania siebie nie tylko jako jedynych prawdziwych obrońców prawosławia, ale chrześcijaństwa w ogóle.

Zaangażowanie Rosji w działania zbrojne na wschodzie Ukrainy skłania do zastanowienia się nad charakterem tego konfliktu. Pod tym względem nie ma jednolitych poglądów. Prokurator Międzynarodowego Trybunału Karnego (MTK) oraz niektórzy przedstawiciele doktryny wskazują na niemiędzynarodowy charakter konfliktu pomiędzy separatystycznymi republikami a rządem ukraińskim, przy równoległym istnieniu międzynarodowego konfliktu zbrojnego rosyjsko-ukraińskiego, począwszy od 17 lipca 2014 r. (Lachowski, 2018, s. 32). Jednak wydaje się, że konflikt na wschodzie Ukrainy całościowo może być traktowany jako międzynarodowy konflikt zbrojny. Świadczy o tym znaczące zaangażowanie zbrojne Rosji po 
stronie separatystycznych republik. Federacja Rosyjska bowiem nie tylko sprawuje kontrolę nad separatystami, której charakter trudno jednoznacznie określić („efektywna” czy „ogólna”), ale także prowadzi bezpośrednie działania zbrojne $\mathrm{z}$ udziałem swoich wojsk, co podnoszone jest praktycznie od początku konfliktu, zarówno przez władze ukraińskie, jak i organizacje pozarządowe. Najbardziej wyrazistym przykładem był tutaj incydent w Cieśninie Kerczeńskiej 25 listopada 2018 r., w postaci „otwartego ataku” jednostek rosyjskich na ukraińskie, jednak, jak słusznie podkreśla się w literaturze, pierwsze użycie siły przez Rosję nastąpiło już w końcu lutego 2014 r. na Krymie. Od tego właśnie momentu można mówić o stanie międzynarodowego konfliktu zbrojnego, zaś prowadzenie działań zbrojnych w Donbasie przez Federację Rosyjską stanowi jedynie kolejną odsłonę agresji rozpoczętej wraz z aneksją Krymu (Lachowski, 2018, s. 32-33).

Odnośnie statusu prawnego DRL i ŁRL należy stwierdzić, że obydwie separatystyczne republiki spełniają w zasadzie kryteria państw de facto (określanych też jako parapaństwa czy quasi-państwa), gdyż dysponują określonym terytorium, ludnością stale zamieszkującą to terytorium oraz władzami sprawującymi rzeczywistą kontrolę nad terytoriami, do których zgłaszają swoje roszczenia (Hoch, Kopeček, 2020, s. 13). Na sposób postrzegania podmiotowości obydwu separatystycznych republik wpływa jednak fakt, że ich powstanie jest bezpośrednim efektem zaangażowania Rosji, której rola w działaniach separatystów była inspirująca i wiąże się z dokonanym przez to państwo aktem agresji. Interwencja Rosji nie może być przy tym traktowana jako interwencja militarna na zasadzie koncepcji „odpowiedzialności za ochronę" (responsibility to protect) czy interwencji humanitarnej (Lachowski, 2018, s. 34). Obydwie separatystyczne republiki są też całkowicie zależne od Rosji, która w rzeczywistości nie chce ich niepodległości, a zamiast tego preferuje stan, gdzie pozostają one częścią Ukrainy, będąc jednocześnie czynnikiem destabilizującym i tym samym służąc interesom Rosji (Hoch, Kopeček, 2020, s. 149). Wskazane powyżej okoliczności powstania DRL i ŁRL (a przede wszystkim agresja z zewnątrz, będąca naruszeniem normy ius cogens) przesądzają o ich nielegalności. Z kolei zarówno w świetle prawa zwyczajowego, jak też z dokumentów ONZ (rezolucje Rady Bezpieczeństwa ONZ w sprawach Rodezji Południowej, Republiki Serbskiej oraz Cypru Północnego, czy też Artykuły o odpowiedzialności międzynarodowej państw za 
akty międzynarodowo bezprawne z 2001 r.) jasno wynika obowiązek nieuznawania sytuacji nielegalnych (Grzywaczewski, 2015, s. 101). Oznacza to, że „władze” obydwu separatystycznych republik w świetle prawa nie istnieją, znajdują się poza jakimkolwiek systemem normatywnym. W przypadku obszarów znajdujących się pod „władzą” DRL i ŁRL mamy zatem do czynienia $\mathrm{z}$ terytoriami będącymi de iure częścią Ukrainy, ale znajdującymi się poza efektywną kontrolą tego państwa, co ma swoje konsekwencje z punktu widzenia tematu artykułu, a o czym jeszcze będzie wspomniane.

\section{Prawa mniejszości wyznaniowych w świetle prawa międzynarodowego}

Kolejny element, na który należy zwrócić uwagę analizując wybrany problem, to akty prawa międzynarodowego odnoszące się do ochrony praw człowieka, gwarantujące określone prawa również mniejszościom wyznaniowym. Wprawdzie poniższe dokumenty dotyczą państw oraz szeroko pojętych członków społeczności międzynarodowej (do których DRL i ŁRL jako podmioty nielegalne nie zaliczają się), jednak, jak wspomniano, tereny zajmowane przez separatystyczne republiki de iure są nadal częścią suwerennego państwa, jakim jest Ukraina. Warto też zwrócić uwagę, że prawa człowieka mają charakter uniwersalny, przysługują każdej osobie, bez względu na to, gdzie i pod czyją władzą znajduje się. Czynniki te powinny stanowić punkt odniesienia przy analizie praw mniejszości wyznaniowych i ich naruszeń, dlatego przytoczenie najważniejszych regulacji prawnomiędzynarodowych w tym zakresie wydaje się zasadne.

Wśród dokumentów odnoszących się do praw mniejszości wyznaniowych należy wymienić m.in. Powszechną Deklarację Praw Człowieka, przyjętą 10 grudnia 1948 r. (Rezolucja Zgromadzenia Ogólnego ONZ 217 A (III)), która stwierdza, że „Każdy człowiek ma prawo do wolności myśli, sumienia i wyznania; prawo to obejmuje swobodę zmiany wyznania lub wiary oraz swobodę głoszenia swego wyznania lub wiary bądź indywidualnie, bądź wespół z innymi ludźmi, publicznie i prywatnie, poprzez nauczanie, praktykowanie, uprawianie kultu i przestrzeganie obyczajów”. Należy podkreślić rolę tego właśnie dokumentu, gdyż, pomimo początkowo niewiążącego charakteru, z czasem doszło do przekształcenia się jego zapisów w zwyczaj 
międzynarodowy (Bierzanek, Symonides, 2005, s. 270 i 271), ten zaś jest obowiązujący dla wszystkich członków społeczności międzynarodowej, w odróżnieniu od umów międzynarodowych, wiążących co do zasady tylko ich strony. Spośród innych ważnych regulacji w tym zakresie warto wspomnieć o art.14 Konwencji o ochronie praw człowieka i podstawowych wolności z 4 listopada 1950 r. (Dz. U. 1993, nr 61, poz. 284), który nakazuje zapewnienie korzystania $z$ praw i wolności w niej wymienionych bez dyskryminacji z jakichkolwiek przyczyn, w tym także religijnych. Podobnie zakaz dyskryminacji, m.in. ze względu na religię, wynika $\mathrm{z}$ art. 27 Międzynarodowego paktu praw obywatelskich i politycznych z 16 grudnia 1966 r. (Dz. U. 1977, nr 38, poz. 167), stanowiącego, że „W Państwach, w których istnieją mniejszości etniczne, religijne lub językowe, osoby należące do tych mniejszości nie mogą być pozbawione prawa do własnego życia kulturalnego, wyznawania i praktykowania własnej religii oraz posługiwania się własnym językiem wraz z innymi członkami danej grupy”, oraz z art.2 ust.2 Międzynarodowego paktu praw gospodarczych, społecznych i kulturalnych z 19 grudnia $1966 \mathrm{r}$. (Dz. U. 1977, nr 38, poz. 169), zgodnie z którym „Państwa Strony niniejszego Paktu zobowiązują się zagwarantować wykonywanie praw wymienionych w niniejszym Pakcie bez żadnej dyskryminacji ze względu na rasę, kolor skóry, płeć, język, religię, poglądy polityczne lub inne, pochodzenie narodowe lub społeczne, sytuację majątkową, urodzenie lub jakiekolwiek inne okoliczności”. Wreszcie, przykładem dokumentu ustanawiającego wyraźny zakaz dyskryminacji mniejszości religijnych (i powiązany z nim nakaz ich ochrony) jest Deklaracja praw osób należących do mniejszości narodowych lub etnicznych, religijnych i językowych z 10 grudnia 1992 r. (Rezolucja Zgromadzenia Ogólnego ONZ 47/135).

\section{Naruszenia praw mniejszości wyznaniowych na terenie Donieckiej Republiki Ludowej i Ługańskiej Republiki Ludowej}

Przechodząc już do analizy sytuacji mniejszości wyznaniowych na terenie DRL i ŁRL, należy wyjść od początku konfliktu zbrojnego i skrótowo przedstawić stosunek kluczowych instytucji religijnych na Ukrainie do separatyzmu na wschodzie tego kraju. Przede wszystkim trzeba zaznaczyć, że pod tym względem instytucje te zajęły niejednolite stanowisko w obliczu 
proklamowania niepodległości obydwu republik. I tak, Wszechukraińska Rada Kościołów i Organizacji Religijnych (skupiająca Kościoły i wspólnoty chrześcijańskie, żydowskie oraz muzułmańskie) jednoznacznie poparła władze centralne Ukrainy, potępiając działania separatystów i podkreślając doniosłość obrony integralności terytorialnej kraju. Natomiast władze Ukraińskiej Cerkwi Prawosławnej Patriarchatu Moskiewskiego (wchodzącej zresztą również w skład wspomnianej Rady) nie zajęły jednoznacznego stanowiska. Wprawdzie jej zwierzchnik apelował do separatystów o złożenie broni, to jednak nie potępił ich działań. Z kolei inni prominentni duchowni tego Kościoła (biskupi doniecki oraz gorłowski i słowiański) postanowili nie zajmować stanowiska w tej sprawie, apelując jedynie o niedopuszczenie do rozlewu krwi, zaś część duchownych w Donbasie i w południowo-wschodnich obwodach Ukrainy wyraźnie wsparła działania na rzecz odłączenia się od tego państwa (Lubicz Miszewski, 2015, s. 82-85). Można zatem stwierdzić, że Ukraińska Cerkiew Prawosławna Patriarchatu Moskiewskiego przyjęła postawę co najmniej „życzliwej neutralności” wobec separatystów, choć należy też zaznaczyć, że wraz z eskalacją konfliktu liczba duchownych popierających działania separatystów malała, ustępując coraz bardziej apelom o deeskalację działań zbrojnych (Jędraszczyk, 2018, s. 199 i 208).

Konsekwencją powyższej sytuacji jest wrogość separatystów wobec tych wszystkich wyznań, które nie należą do Patriarchatu Moskiewskiego. Otwartą niechęć budzą duchowni i wierni z Ukraińskiej Cerkwi Prawosławnej Patriarchatu Kijowskiego, a obecnie Cerkwi Prawosławnej Ukrainy (którzy traktowani są jako zdrajcy „prawdziwego" prawosławia, utożsamianego przez separatystów z Patriarchatem Moskiewskim), ale także katolicy obydwu obrządków i wyznawcy Kościołów ewangelikalnych (Lubicz Miszewski, 2015, s. 85). Szczególnie narażeni na represje są wyznawcy różnych odłamów protestantyzmu, zwłaszcza niewielkich wspólnot, gdyż są to wyznania, za którymi nie stoi znacząca siła instytucjonalna (tak jak ma to miejsce np. w przypadku Kościoła Katolickiego) i w związku z tym represje wobec nich nie znajdują wystarczająco dużego nagłośnienia w świecie.

Jeśli chodzi o charakter naruszeń praw mniejszości wyznaniowych, to niestety wspomniana powyżej niechęć ze strony separatystów nie przybiera jedynie formy wyrażania nieprzychylnych opinii czy ostracyzmu, ale także czynów noszących znamiona jawnych represji. Działania takie miały miejsce 
już w pierwszych miesiącach konfliktu i polegały na zatrzymywaniu, porywaniu, a niekiedy także torturowaniu duchownych. Instrumentem szerzenia terroru było również zastraszanie kapłanów, co w konsekwencji miało na celu wzbudzenie strachu wśród samych wiernych. Takim przykładem może być tutaj porwanie o. Tichona z Ukraińskiej Cerkwi Greckokatolickiej, który po 11 dniach został wypuszczony z więzienia i zmuszony do natychmiastowego wyjazdu $z$ Doniecka z kategorycznym zakazem informowania o tym, w jakich warunkach był przetrzymywany, gdyż w przeciwnym razie zemsta miałaby objąć jego parafian (Lubicz Miszewski, 2015, s. 86). Innym przykładem może być sprawa zastraszania J. Pronina, pastora Kościoła Odrodzenia w Pierwomajsku (obwód ługański), zakończona podpaleniem świątyni (Religious Persecution..., 2014, s. 110-111). Na terenach znajdujących się pod kontrolą separatystów zdarzały się również zabójstwa duchownych. W czerwcu 2014 r. doszło do porwania, a następnie do zamordowania dwóch diakonów i dwóch synów miejscowego pastora Kościoła Chrześcijan Wiary Ewangelicznej, sprzyjających władzom centralnym i popierających działania armii ukraińskiej (Lubicz Miszewski, 2015, s. 86). Oprócz tego rodzaju najbardziej drastycznych działań, notowano także przypadki grabieży majątku kościelnego należącego do protestantów, grekokatolików, parafii katolickich i prawosławnych oraz zajmowanie dla „potrzeb separatystów” budynków, sprzętów biurowych, mebli, samochodów czy dokumentów (Jędraszczyk, 2018, s. 198).

W późniejszym czasie charakter represji uległ pewnej ewolucji, a mianowicie zaczęły być one uzasadniane pozorami prawnego porządku i rzekomych akcji ze strony społeczeństwa obywatelskiego. Przybierały postać zamykania świątyń czy organizowania demonstracji. Praktyka zamykania świątyń dotknęła np. Świadków Jehowy na terenach zarówno DRL, jak i ŁRL, gdzie w 2015 r. doszło do zamknięcia szeregu sal Królestwa, należących do tych wspólnot religijnych (Religious Buildings..., 2015). Z kolei przykładem „akcji społecznych” może być demonstracja ze stycznia 2016 r., kiedy manifestanci zebrani przed unickim kościołem Opieki Najświętszej Bogurodzicy w Doniecku oskarżali przedstawicieli Kościoła katolickiego obrządku bizantyjsko-ukraińskiego o to, że są oni „sekciarzami”, którzy gnębią prawosławnych i zakłócają porządek publiczny na zlecenie CIA (Tatarenko, 2017, s. 31). Zatem w tym wypadku przekaz kierowany był do pozostałej ludności zamieszkującej tereny znajdujące się pod władzą separatystów, a cel 
stanowiło wskazanie zagrożenia dla wyznawców prawosławia, które (zdaniem separatystów) wywołują wyznawcy innych religii, a ponadto zasugerowanie, że działają oni z inspiracji zewnętrznej (zachodniej), co miało wzbudzać dodatkową niechęć oraz zjednoczenie społeczeństwa wokół „władz” samozwańczych republik. Jednak warto zwrócić uwagę, że czynnik religijny, który odgrywał dość znaczącą rolę w początkowej fazie konfliktu, w późniejszym czasie uległ osłabieniu. O ile bowiem początkowo prawosławie było traktowane jako jeden z fundamentów założycielskich obydwu republik, a sama rebelia przez część bojowników rozumiana była jako walka w obronie wiary, to $\mathrm{z}$ biegiem czasu do tych aspektów przywiązywano coraz mniejszą wagę. Przykładem może być tutaj dokonana w 2015 r. zmiana nazwy jednostki wojskowej DRL, nazywanej pierwotnie Rosyjskie Wojsko Prawosławne, na Wympel, z wyraźnym odniesieniem do elitarnej grupy służb rosyjskich o tej samej nazwie. Prawdopodobnie uznano, że posługiwanie się argumentami religijnymi straciło swoją skuteczność w trakcie konfliktu, a wręcz stało się szkodliwe z punktu widzenia wizerunku separatystów na arenie międzynarodowej (Tatarenko, 2017, s. 35).

Walkę z poszczególnymi wyznaniami, traktowanymi jako wrogie, podjęto jednak za pomocą instrumentów prawnych. Przykładem tego rodzaju działań może być uchwalenie w maju 2018 r. w DRL nowelizacji ustawy O wolności religii i związków wyznaniowych. Zgodnie z jej treścią, wszystkie religijne organizacje, poza Cerkwią Prawosławną Patriarchatu Moskiewskiego, są zobowiązane przejść rejestrację jako Cerkwie należące do republiki. Wydaje się, że ruch ten był wymierzony przede wszystkim w Cerkiew Prawosławną Ukrainy ${ }^{1}$, która odmawia dokonania takiej rejestracji, argumentując, że ustawa została wydana przez podmiot nie uznawany przez nikogo za państwo. Problem ten dotyczy także baptystów, którzy również odmówili rejestracji zgodnie z nowymi przepisami (Ukraina: Prześladowanie Cerkwi..., 2019). „Twardy kurs” kontynuowano także wobec stowarzyszenia Świadków Jehowy, które 26 września 2018 r. Sąd Najwyższy Donieckiej Republiki

1 Cerkiew Prawosławna Ukrainy powstała w grudniu 2018 r. w wyniku zjednoczenia Ukraińskiej Cerkwi Prawosławnej Patriarchatu Kijowskiego i Ukraińskiej Autokefalicznej Cerkwi Prawosławnej. W jej skład weszła również niewielka część struktur Ukraińskiej Cerkwi Prawosławnej Patriarchatu Moskiewskiego, uznawanej wcześniej przez światowe prawosławie za jedyny kanoniczny Kościół na Ukrainie (Piechowska, 2020, s. 1). 
Ludowej uznał za organizację ekstremistyczną i zakazał jego działalności. Jednocześnie trwała też praktyka zamykania sal Królestwa, należących do wspomnianego stowarzyszenia ("Donetsk Peoples Republic" Bans..., 2018). Wszystko to świadczy o tym, że zwalczanie organizacji religijnych innych niż Cerkiew Prawosławna Patriarchatu Moskiewskiego przybiera coraz częściej formę działań instytucjonalno-prawnych, które zresztą stoją w sprzeczności z najwyższym prawodawstwem ustanowionym przez „władze” separatystycznych republik. Konstytucje DRL i ŁRL (obydwie zawierające pod tym względem identyczne zapisy) stanowią bowiem, że „Państwo gwarantuje równość praw i wolności człowieka i obywatela, bez względu na płeć, rasę, narodowość, język, pochodzenie, status majątkowy i zajmowane stanowisko, miejsce zamieszkania, religię, przekonania, członkostwo w stowarzyszeniach publicznych lub inne okoliczności. Wszelkie formy ograniczania praw obywateli ze względu na przynależność społeczną, rasową, narodową, językową lub religijną są zabronione" (art. 13 Konstytucji DRL i Konstytucji ŁRL). Należy przy tym podkreślić, że wspomniane „ustawy” (podobnie zresztą jak przyjęte „konstytucje”) nie mają jakiejkolwiek mocy prawnej, co jest konsekwencją nielegalności obydwu republik. Ich utworzenie w następstwie naruszenia bezwzględnie wiążącej normy prawa międzynarodowego skutkuje tym, że $\mathrm{w}$ świetle prawa DRL i ŁRL nie istnieją, a co za tym idzie, pozbawione są znaczenia prawnego praktycznie wszystkie przepisy wydawane przez ich „władze”. Pogląd ten znajduje potwierdzenie w stanowisku Międzynarodowego Trybunału Sprawiedliwości, który już znacznie wcześniej w opinii doradczej w sprawie skutków prawnych obecności Afryki Południowej w Namibii z 21 czerwca 1971 r. stwierdził, że takie „akty” cechują się nielegalnością i nieważnością (Legal Consequences for States of the Contitiued Presence of South Africa in Namibia (South West Africa) notwithstanding Security Council Resolution 276 (1970), Advisory Opinion, I.C.J. Reports 1971, p. 16)². Jakkolwiek zatem wskazane powyżej przykłady łamania własnych „,konstytucji” nie mają żadnej mocy prawnej, to jednak wskazują jednoznacznie brak dobrej woli ze strony DRL i ŁRL w stosunku do mniejszości wyznaniowych, stanowiąc przy tym kolejny przykład naruszeń ich praw.

2 Obowiązek uznawania za nielegalne „aktów prawnych” wydawanych przez RPA nie dotyczył aktów stanu cywilnego, takich jak rejestracje urodzin, zgonów i zawartych małżeństw. 
Wreszcie, w literaturze można spotkać się z informacją, że w lutym 2019 r. Służba Bezpieczeństwa Ukrainy poinformowała o udaremnionych planach służb DRL destabilizacji sytuacji wyznaniowej na Ukrainie poprzez napady, podpalenia oraz użycie gróźb wobec duchownych. Celami działań finansowanych przez DRL miały być wspólnoty Ukraińskiej Cerkwi Prawosławnej Patriarchatu Moskiewskiego oraz Kościoła Katolickiego (Myślicki, 2019, s. 110). Oznaczałoby to, że separatyści wykorzystują swoje służby specjalne w celu walki grupami wyznaniowymi, stosując różne elementy prowokacji. Jednak trudno do końca ocenić wiarygodność tych doniesień, gdyż trzeba pamiętać, że strona rządowa w tym konflikcie również szeroko posługuje się instrumentami wojny informacyjnej.

\section{Problem odpowiedzialności prawnej za naruszenia praw mniejszości wyznaniowych na terenie Donieckiej Republiki Ludowej i Ługańskiej Republiki Ludowej}

Odnosząc się do podanych powyżej przykładów należy stwierdzić, że mogą być one traktowane jako naruszenia praw mniejszości wyznaniowych (gwarantowanych również przytoczonymi wcześniej regulacjami prawa międzynarodowego), a tym samym powinny skutkować odpowiedzialnością prawną. Pod tym względem pojawiają się jednak pewne problemy. Po pierwsze, należy zastanowić się, kto miałby tę odpowiedzialność ponosić. Z całą pewnością powinno to odnosić się do bezpośrednich sprawców dokonanych naruszeń. Teoretycznie osoby takie powinny być ścigane przez wymiar sprawiedliwości Ukrainy bądź nieistniejących de iure separatystycznych republik. W praktyce jednak organy ścigania Ukrainy na terenach będących pod władzą separatystów nie mają jakiejkolwiek możliwości prowadzenia czynności procesowych, zmierzających do ustalenia sprawców i pociągnięcia ich do odpowiedzialności karnej. Natomiast możliwości takie mają „władze” DRL i ŁRL, które - jeżeli rzeczywiście dążyłyby do uzyskania podmiotowości - powinny, zgodnie z ustanowionymi przez siebie przepisami, podejmować działania mające na celu zapewnienie praworządności na kontrolowanych terenach. Jednakże „władze” te takich kroków nie podejmują, co nie stanowi zaskoczenia, biorąc pod uwagę ich faktyczną politykę wobec mniejszości wyznaniowych oraz rolę, którą faktycznie spełniają (są instrumentem w rękach Rosji, służącym destabilizacji Ukrainy). 
W związku z takim zaniechaniem ścigania ewidentnych naruszeń praw człowieka (czy wręcz aktywnym uczestnictwie w tym procederze), pojawia się pytanie czy odpowiedzialność za naruszanie praw mniejszości wyznaniowych można przypisać (oprócz bezpośrednich sprawców) również „władzom” separatystycznych republik. Odpowiedź na to pytanie jest negatywna. Jak już bowiem wcześniej wspomniano, „władze” DRL i ŁRL w sensie prawnym nie istnieją, a w konsekwencji nie należy przypisywać podmiotom nieistniejącym prawnie jakichkolwiek prawnych obowiązków. Innego rodzaju problem, jaki wiąże się z odpowiedzialnością za naruszenia praw mniejszości wyznaniowych na terenie DRL i ŁRL, wynika z faktu, że obydwie republiki nie podlegają jurysdykcji żadnego sądu międzynarodowego. Republiki te, nie będąc podmiotami prawa międzynarodowego, nie są też stronami Konwencji o ochronie praw człowieka i podstawowych wolności, Międzynarodowego paktu praw obywatelskich i politycznych czy też Międzynarodowego paktu praw gospodarczych, społecznych i kulturalnych, z których wynika obowiązek respektowania praw mniejszości wyznaniowych, a więc w konsekwencji nie mogą ponosić odpowiedzialności na gruncie prawa międzynarodowego.

Odpowiedzialność prawnomiędzynarodową za naruszenia praw mniejszości wyznaniowych mogą ponieść jedynie dwa podmioty: Ukraina (jako państwo, do którego de iure należą tereny zajmowane przez DRL i ŁRL) oraz Federacja Rosyjska (jako państwo-protektor DRL i ŁRL). Jeśli chodzi o ewentualną odpowiedzialność Ukrainy, to współcześnie przyjmuje się, że państwo-suweren może ponosić odpowiedzialność nie tyle za bezprawne działania lub zaniechania nieuznawanego podmiotu, co raczej za swoją porażkę w przedsięwzięciach mających na celu wyeliminowanie lub złagodzenie skutków tego typu bezprawnych zachowań (Zaręba, 2019, s. 192). Warto przy tym zaznaczyć, że na gruncie Konwencji o ochronie praw człowieka i podstawowych wolności na państwie takim ciążą zobowiązania pozytywne, polegające na podejmowaniu odpowiednich kroków dla zapewnienia przestrzegania praw i wolności, także na terytorium znajdującym się pod kontrolą sił separatystycznych. Odnośnie do konfliktu na wschodzie Ukrainy Europejski Trybunał Praw Człowieka (ETPCz) w wyroku w sprawie Khlebik przeciwko Ukrainie z 2017 r. stwierdził, że Ukraina powzięła wszelkie starania, żeby zagwarantować prawa skarżącego i nie odpowiada w świetle zobowiązań negatywnych za naruszenia Konwencji na obszarze ŁRL. 
Trybunał wskazał ponadto, że Ukraina podjęła również skuteczne działania, żeby dostosować swój system sądownictwa do sytuacji trwającego konfliktu zbrojnego, do którego dostęp mają również osoby przebywające na stałe na obszarach znajdujących się poza kontrolą władz w Kijowie. Podobnie w sprawie Tsezar i inni przeciwko Ukrainie (odnoszącej się z kolei do mieszkańców DRL) ETPCz również nie stwierdził naruszenia przez Ukrainę praw płynących z Konwencji. Jednak, jak słusznie podkreśla się w literaturze, na gruncie zobowiązań pozytywnych Ukraina w innych sprawach wciąż może być uznana za odpowiedzialną za naruszenia praw człowieka w ŁRL i DRL (Lachowski, 2018, s. 47-48).

Z kolei gdy chodzi o Rosję, to jej odpowiedzialność jako państwa-protektora jest zależna od ustalenia, że sprawuje ona „efektywną (ogólną) kontrolę” nad separatystycznymi „władzami”. Dowodem na to może być obecność militarna, czy też zakrojone na szeroką skalę wsparcie polityczne, logistyczne czy ekonomiczne dla separatystów (Lachowski, 2018, s. 45-46), jednak fakt istnienia takiej kontroli musiałby zostać stwierdzony przez sąd, do którego kierowana byłaby dana skarga wobec Rosji. W takim ujęciu, nieuznawane podmioty postrzegane byłyby zatem jedynie jako ,agenci” państwa, które je wspiera (Zaręba, 2019, s. 192), co umożliwiałoby zdeterminowanie odpowiedzialności Federacji Rosyjskiej jako państwa-protektora.

Warto tutaj zauważyć, że w przypadku analizowanego konfliktu kroki sądowe w stosunku do Rosji rzeczywiście Ukraina próbuje podejmować. Praktyka taka stosowana jest w różnych sprawach związanych $\mathrm{z}$ aneksją Krymu i konfliktem na wschodzie kraju (Nieczypor, 2018, s. 1-8). Przykładem są tutaj skargi kierowane do ETPCz, gdzie Ukraina zarzucając Rosji, że ta, sprawując zarówno na Krymie, jak również na Donbasie „efektywną ogólną kontrolę” tak nad obszarem, jak i nad „lokalnymi władzami” oraz tzw. separatystami, wskazuje, że Federacja Rosyjska dopuściła się naruszeń m.in. prawa do wolności religijnej (Lachowski, 2018, s. 43). Ukraina mogłaby też dołączyć się do indywidualnych skarg, jeżeli takie kierowane byłyby przez członków mniejszości wyznaniowych do ETPCz przeciwko Rosji, w związku z działaniami podejmowanymi przeciwko nim na terytorium ukraińskim (Kamiński, 2015, s. 134). Tego typu działania prawne przeciwko Rosji potencjalnie mogą być do pewnego stopnia skuteczne. W swojej decyzji z 16 grudnia 2020 r. ETPCz uznał międzypaństwową skargę „Ukraina przeciwko 
Rosji” dotyczącą okupacji Krymu (20958/14 i 38334/18) za dopuszczalną, stwierdzając przy tym, że Federacja Rosyjska sprawuje efektywną kontrolę nad Krymem od 27 lutego 2014 r. Otwiera to z kolei drogę do merytorycznego rozpatrzenia skargi, stwierdzenia czy doszło do konkretnych naruszeń praw człowieka i czy Rosja ponosi za nie odpowiedzialność (Europejski Trybunał Praw Człowieka..., 2021). Decyzja ta wprawdzie dotyczy sytuacji na Krymie, jednak wskazano w niej także na naruszenia przez Rosję postanowień Konwencji o ochronie praw człowieka i podstawowych wolności w zakresie wolności religijnej. Biorąc pod uwagę wskazany powyżej charakter zaangażowania Rosji na „terytoriach” DRL i ŁRL, nie można wykluczyć, że podobne wnioski ETPCz może wyciągnąć również w tym przypadku, przy czym, jak wcześniej wskazano, Trybunał musi określić najpierw charakter kontroli Rosji nad Donbasem (skargi dotyczące Donbasu nie zostały jeszcze rozpoznane).

Jednak należy podkreślić, że powyższe rozwiązania prawne nie rozwiązują do końca problemu (zwłaszcza, że faktyczni sprawcy represji nadal pozostają bezkarni), natomiast tak naprawdę dopiero ostateczne zakończenie konfliktu zbrojnego może stanowić przełom pod tym względem. Ostateczne i wiążące uregulowanie statusu prawnego wschodnich terenów Ukrainy, przywracające jej efektywną kontrolę nad nimi, ale jednocześnie uwzględniające najdalej jak to możliwe interesy wszystkich zainteresowanych stron, a także stworzenie nowych, demokratycznie wybranych władz samorządowych, szanujących prawa całokształtu ludności, a przy tym respektujących normy prawa wewnętrznego i międzynarodowego, jak również rozliczenie przestępstw popełnionych w czasie konfliktu (przy czym należy pamiętać, że dopuszczały się ich wszystkie strony), stworzyłyby realną szansę na przywrócenie praworządności na tym obszarze, a tym samym na poprawę sytuacji znajdujących się tam mniejszości wyznaniowych.

\section{Wnioski}

Podsumowując, przeprowadzona analiza skłania do wyciągnięcia następujących wniosków końcowych:

- w przypadku DRL i ŁRL można mówić o naruszaniu praw mniejszości wyznaniowych już od samego początku trwania konfliktu zbrojnego na wschodzie Ukrainy. Podłoże tych naruszeń nie dotyczy przy tym 
różnic na tle teologicznym, lecz bardziej o charakterze politycznym, co związane jest z poparciem udzielonym przez ukraińskie związki religijne rządowi centralnemu w Kijowie (wyjątek stanowiła tutaj niejednoznaczna postawa Ukraińskiej Cerkwi Prawosławnej Patriarchatu Moskiewskiego). Dodatkowym powodem nieprzychylności (zwłaszcza w przypadku wyznań nieprawosławnych) jest sposób ich postrzegania przez separatystów jako elementu obcego kulturowo, nieprzystającego do statusu republik, traktowanych jako część „Świętej Rusi” podległej wyłącznie Patriarchatowi Moskiewskiemu. Ponadto „władze” separatystyczne uzasadniają swoje działania rzekomym agenturalnym charakterem represjonowanych grup wyznaniowych i ich działaniem na zlecenie wywiadów państw zachodnich;

- z upływem czasu następowało zmniejszenie roli kwestii religijnych jako elementów konstytuujących tożsamość DRL i ŁRL, co jednak nie oznaczało zaprzestania naruszania praw mniejszości wyznaniowych. Zmienił się przy tym charakter tych represji, które przestawały być prowadzone w sposób chaotyczny, niezorganizowany, niekiedy oddolny, a zaczęły przybierać formę zinstytucjonalizowaną. Może to wiązać się z okrzepnięciem „struktur władzy” separatystycznych republik, a przy tym chęcią nadania działaniom represyjnym pozorów legalności;

- możliwość pociągnięcia do odpowiedzialności sprawców naruszeń jest w praktyce bardzo utrudniona, $\mathrm{z}$ uwagi na brak kontroli władz centralnych Ukrainy nad terenami zajętymi przez separatystów, którzy korzystają przy tym z pomocy Rosji, zapewniającej im swego rodzaju „parasol ochronny”. Z kolei „władze” DRL i ŁRL, jako podmioty nie istniejące $\mathrm{w}$ świetle prawa, nie mogą ponosić odpowiedzialności na gruncie prawa międzynarodowego;

- warunkiem sine qua non przywrócenia faktycznych rządów prawa na obszarach DRL i ŁRL oraz poprawy sytuacji znajdujących się tam mniejszości wyznaniowych jest zakończenie konfliktu zbrojnego i ostateczne, prawnie wiążące uregulowanie statusu wschodnich terenów Ukrainy w taki sposób, aby ich status de facto pokrywał się ze statusem de iure. 


\section{DR HAB. ADRIAN SZUMSKI}

Instytut Studiów Międzynarodowych

Wydział Nauk Społecznych

Uniwersytet Wrocławski

ul. Koszarowa 3, 51-149 Wrocław

e-mail: adrian.szumski@uwr.edu.pl

\section{Bibliografia}

Bierzanek, R., Symonides, J. (2005). Prawo międzynarodowe publiczne. Warszawa: LexisNexis.

Deklaracja praw osób należacych do mniejszości narodowych lub etnicznych, religijnych i językowych z 10 grudnia 1992 r. Rezolucja Zgromadzenia Ogólnego ONZ 47/135.

Delong, M. (2020). „Ruski mir” jako narzędzie rosyjskiej ekspansji geopolitycznej na terytorium Ukrainy. Przegląd Geopolityczny, 33, 50-64.

"Donetsk People’s Republic"Bans Jehovah's Witnesses.(2021,26 kwietnia).Pobrane z: https:// www.jw.org/en/news/jw/region/ukraine/donetsk-peoples-republic-bans-jehovahs -witnesses/.

Europejski Trybunał Praw Człowieka zajmie się naruszeniami praw człowieka na Krymie. (2021, 12 lipca). Pobrane z: https://www.hfhr.pl/europejski-trybunal-praw-czlowieka-zajmie-sie-naruszeniami-praw-czlowieka-na-krymie/.

Gaufman, E. (2020). Come all ye faithful to the Russian world: governmental and grass-roots spiritual discourse in the battle over Ukraine. W: E.A. Clark, D. Vovk (red.). Religion During the Russian-Ukrainian Conflict (54-68). New York: Routledge.

Grzywaczewski, T. (2015). „Ludowe republiki Donbasu” - granice prawa do samostanowienia a fenomen quasi-państw. Studia Prawnicze KUL, 2(62), 77-106.

Hoch, T., Kopeček, V. (red.). (2020). De Facto States in Eurasia. New York: Routledge. Jędraszczyk, J. (2018). Cerkiew prawosławna na Ukrainie i w Rosji po 2013 r. wobec wyzwań politycznych, konfliktu rosyjsko-ukraińskiego oraz pytań o granice suwerenności. Przegląd Zachodni, 1, 198-208.

Kamiński, I.C. (2015). Gdzie i jak mogą się skarżyć uczestnicy konfliktu na Ukrainie? Studia Prawnicze KUL, 2(62), 107-139.

Konstytucja Donieckiej Republiki Ludowej z dn. 14 maja 2014 r.

Konstytucja Ługańskiej Republiki Ludowej z dn. 18 maja 2014 r.

Konwencja o ochronie praw człowieka i podstawowych wolności z dn. 4 listopada 1950 r. Dz. U. 1993, nr 61, poz. 284.

Lachowski, T. (2018). Prawo międzynarodowe praw człowieka jako instrument przeciwdziałania skutkom poważnego naruszenia prawa międzynarodowego publicznego analiza wybranych aspektów przypadku agresji Federacji Rosyjskiej wobec Ukrainy (w latach 2014-2018). Wschodni Rocznik Humanistyczny, Tom XV, No. 4, 25-58.

Legal Consequences for States of the Contitiued Presence of South Africa in Namibia (South West Africa) notwithstanding Security Council Resolution 276(1970), Adrisory Opinion, I.C.J. Reports 1971, p. 16. 
Lubicz Miszewski, M. (2015). Kościoły chrześcijańskie na Ukrainie wobec aneksji Krymu i wojny w Donbasie. Wschodnioznawstwo, 1, 82-86.

Międzynarodowy pakt praw gospodarczych, społecznych i kulturalnych $z$ dn. 19 grudnia 1966 r. Dz. U. 1977, nr 38, poz. 169.

Międzynarodowy pakt praw obywatelskich i politycznych z dn. 16 grudnia 1966 r. Dz.U. 1977, nr 38, poz. 167.

Myślicki, A. (2019). Konflikt konfesyjny na Ukrainie przełomu lat 2018/2019. Przegląd Geopolityczny, 29, 110.

Nieczypor, K. (2018). O sprawiedliwość i odszkodowania. Ukraina przeciwko Rosji w sądach międzynarodowych. Komentarze OSW, 271, 1-8.

Piechowska M. (2020). Cerkiew Prawosławna Ukrainy - rok po uzyskaniu autokefalii. Biuletyn PISM, 37(1969), 1.

Powszechna Deklaracja Praw Człowieka z dn. 10 grudnia 1948 r. Rezolucja Zgromadzenia Ogólnego ONZ 217 A (III).

Religious Buildings Seized in Eastern Regions of Ukraine. (2021, 26 kwietnia). Pobrane z: https://www.jw.org/en/news/legal/by-region/ukraine/donetsk-luhansk-religious -buildings-seized/.

Religious Persecution in Eastern Ukraine and Crimea 2014. (2021, 26 kwietnia). Pobrane z: http://static1.1.sqspcdn.com/static/f/1671274/25949565/1423755477087/Religious+Persecution+in+Eastern+Ukraine+and+Crimea+2014_Redacted.pdf.

Tatarenko, L. (2017). Instytucje religijne i polityka na Ukrainie: zagadnienie tożsamości w czasach wojny. Rocznik Instytutu Europy Środkowo-Wschodniej, 15, 31-35.

Ukraina: Prześladowanie Cerkwi Prawosławnej Ukrainy w Doniecku. (2021, 26 kwietnia). Pobrane z: https://www.gazetaprawna.pl/artykuly/1400591,ukraina-przesladowanie-cerkwi-prawoslawnej-ukrainy-w-doniecku.html.

Zaręba, S. (2019). Responsibility for the Acts of Unrecognised States and Regimes. W: W. Czapliński, A. Kleczkowska (red.). Unrecognised Subjects in International Law (159-193). Warszawa: Scholar Publishing House Ltd. 